\title{
BLOOD VITAMIN D CONCENTRATION IN ADULT ASTHMATIC PATIENTS
}

\author{
Dr. Subinay Datta, *Dr. Mrinal Pal, Tarashankar Malik \\ Department of Biochemistry,Burdwan Medical College,Burdwan, WBUHS, WB, India ,Pin-713104 \\ *Corresponding author's Email: mrinalpal77@rediffmail.com; Mob: 09007593545
}

\begin{abstract}
Background: There has been growing interest in vitamin D insufficiency as a predisposing factor for allergy development based on immunoregulatory properties and epidemiological studies. Little is known about vitamin D in adult asthma patients or its association with asthma severity. Aim: The present study is to assess the relationship between vitamin D status and asthma in adult population. Methods: A cross sectional study including 622 asthmatic adults aged older than 18 years and 617 adults healthy control aged older than 18 years assessing the relationship between serum 25 hydroxy vitamin D levels. Result: The difference between mean vitamin D levels in the asthmatic group $24.96 \pm 5.58 \mathrm{ng} / \mathrm{ml}$ and the healthy control group 32.39 $\pm 5.28 \mathrm{ng} / \mathrm{ml}$ was found to be statistically significant $(\mathrm{p}<0.001)$ and more interestingly there was significant correlation between low 25 OHD level and the severity of asthma. Conclusion: Reduced vitamin D levels are highly prevalent in adult asthmatic patients and are associated severity of the disease.
\end{abstract}

Key words: Asthma, Vitamin D.

\section{INTRODUCTION}

Asthma represents one of the most common chronic diseases and is a major public health problem worldwide. [1] In the majority of patients control of asthma as defined by guidelines can be achieved with long-term maintenance medications. ${ }^{1}$ However, a substantial proportion of patients do not achieve optimal asthma control despite even high dose treatment. In particular inadequately controlled patients with severe persistent asthma are at high risk of severe exacerbations and asthma-related mortality. These patients represent the greatest unmet medical need among the asthmatic population today.

A number of causative factors have been proposed for this including significant changes in lifestyle patterns, nutrient intake, exposure to microbial organisms and air pollution. However, most of these notions cannot individually explain the rise in disease. It seems clear that no one factor is responsible for asthma aetiology and that the condition is probably multifactorial in aetiology as well as clinical expression. Litonjua and Weiss recently offered a new hypothesis to explain the asthma epidemic. ${ }^{2}$ They hypothesized that vitamin D status influences asthma risk, although they had direct evidence of a relationship only among pregnant women and their offspring. Whether vitamin D status is associated with adult asthma remains unclear. Moreover, recently variations in vitamin $\mathrm{D}$ status and intake has been implicated in allergy development and considered as one of a number of explanations for epidemiological and immunological associations. So, the aim of the present study is to assess the relationship between vitamin D status and asthma in adult population.

\section{MATERIAL AND METHODS}

\subsection{Study area}

This hospital based cross-sectional study was conducted in the pulmonary clinics with the collaboration of
Department of Biochemistry of Burdwan Medical College, Burdwan, West Bengal, India.

\subsection{Selection of subjects}

A total of 622 from 1846 patients aged 18-60 years who had been diagnosed with asthma who attended Burdwan Medical College of Burdwan district were selected as case and 617 subjects having no asthma as age and sexmatched control by simple random sampling after informed consent had been received between February 2011 and October 2013. The subjects were diagnosed according to the Global Initiative for Asthma (GINA) criteria: 1) a physician's diagnosis of asthma, 2) symptoms of recurrent (i.e. more than two) episodes of wheezing, cough, shortness of breath, or a combination of these, 3) documented reversibility with bronchodilators, and 4) symptoms of and/or use of medication for asthma in the previous six months ${ }^{3}$. They were divided into Mild intermittent, Mild persistent, Moderate persistent and severe persistent using same guideline. Based on clinical history taking and clinical records, patients with human immunodeficiency virus (HIV) infection, hepatic disease, renal failure, malignancy, diabetes mellitus, pregnancy, sarcoidosis, hyperparathyroidism or those taking any corticosteroids, immunosuppressive agents, thiazide diuretics or drugs known to interfere with vitamin D levels (phenytoin, phenobarbital, carbamazepine, theophylline) were excluded from the study. Asthma diagnosis was made based on the patients symptoms plus objective evidence from pulmonary function tests according to the criteria defined by the American thoracic Society in 1987.

\subsection{Pulmonary function tests}

Pulmonary function was measured both pre-and postinhalation of $0.4 \mathrm{mg}$ salbutamol, on a spirometer (HELIOS 401) by trained study staff. As the FEV 1 is the most reproducible lung function test parameter therefore is best adopted to assessment of large group of people. 
Spirometric values were postbronchodilator measurements, and absolute values were expressed as percentage predicted of reference values. ${ }^{4}$

\subsection{Collection of samples}

Peripheral venous blood was drawn and allowed to coagulate at room temperature for 30-45 min, followed by centrifugation at $2500 \mathrm{Xg}$ for $15 \mathrm{~min}$. All serum samples were stored at $-70^{\circ} \mathrm{C}$ and kept under these conditions until chemical analysis was performed.

\subsection{Parameters assay}

Serum 25(OH)D was estimated by enhanced chemiluminescent assay (ECI) using instrument VITROS eci (Johnson \&Johnson) \& dedicated reagent. ${ }^{5}$ The inter$\&$ intra-assay coefficients of variation were $6.4 \& 5.7 \%$.

\subsection{Statistical analysis}

All data were statistically analyzed using Student's $t$-test, and chi-square (linear by linear correlation) tests, as applicable (with a preset probability of $\mathrm{p}<0.05$ ). Experimental results are presented as arithmetic mean \pm $\mathrm{SD}$. The data for biochemical analysis was subjected to standard statistical analysis using the Statistical Package for Social Science (SPSS) 11.5 software for windows.

\section{RESULT}

\subsection{The characteristics of the study population}

Analysis of demographic characteristics of the studied groups revealed that except FEV1 and eating habits there were insignificant differences between patients and controls as regard age, sex, BMI and residence (table 1).

Table 1: Baseline personal profile and clinical details of the study population

\begin{tabular}{|c|c|c|c|}
\hline Demographic profiles & Asthmatic patients & Control population & $p$ value \\
\hline $\mathrm{n}$ & 622 & 617 & $>0.05$ \\
\hline Age (Years) & $35.71 \pm 11.84$ & $34.92 \pm 10.12$ & $>0.05$ \\
\hline $\begin{array}{l}\text { Sex } \\
\quad \text { Male } \\
\text { Female } \\
\end{array}$ & $\begin{array}{l}310(49.8) \\
312(50.2) \\
\end{array}$ & $\begin{array}{l}307(49.7) \\
310(50.3) \\
\end{array}$ & $>0.05$ \\
\hline BMI $\left(\mathrm{Kg} / \mathrm{m}^{2}\right)$ & $24.29 \pm 5.14$ & $24.11 \pm 4.82$ & $>0.05$ \\
\hline $\begin{array}{c}\text { Residence } \\
\text { Urban } \\
\text { Rural } \\
\end{array}$ & $\begin{array}{l}293 \\
329 \\
\end{array}$ & $\begin{array}{l}291 \\
326 \\
\end{array}$ & \\
\hline FEV1 & $52.78 \pm 18.56$ & $80.28 \pm 9.28$ & $<0.05$ \\
\hline $\begin{array}{l}\text { Severity of asthma } \\
\text { Intermittent } \\
\text { Mild } \\
\text { Moderate } \\
\text { Severe }\end{array}$ & $\begin{array}{l}223(35.8) \\
198(31.8) \\
167(26.8) \\
34(5.4)\end{array}$ & & \\
\hline $\begin{array}{l}\text { Eating habits } \\
\text { D vitamin insufficient } \\
\text { D vitamin sufficient }\end{array}$ & $\begin{array}{l}499 \\
123 \\
\end{array}$ & $\begin{array}{l}235 \\
382 \\
\end{array}$ & $<0.05$ \\
\hline
\end{tabular}

\subsection{Comparison of the serum vitamin $D$ level between two study groups - unpaired t test}

It was showed a highly significant decrease in serum 25OHD concentration in group with asthma than in control group (table 2).

Table 2: Comparison between asthma and control group as regard serum 25-OHD

\begin{tabular}{|l|l|l|l|l|}
\hline Parameter & Case & Control & t & p value \\
\hline Serum 25(OH)D concentration $(\mathbf{n g} / \mathbf{m l})$ & $24.96 \pm 5.58$ & $32.39 \pm 5.28$ & 4.038 & $<0.001$ \\
\hline
\end{tabular}

\subsection{Comparison of the serum vitamin D level with the severity of asthma - unpaired $t$ test}

The lowest levels of 25(OH)D was found in patients with moderate persistent and severe persistent asthma (table 3).

Table 3: Relation between 25(OH) D levels and the severity of asthma

\begin{tabular}{|c|c|c|l|l|}
\hline Parameter & $\begin{array}{c}\text { Mild intermittent and mild } \\
\text { persistent asthma } \\
(\mathbf{n = 3 2 2})\end{array}$ & $\begin{array}{c}\text { Moderate and severe } \\
\text { persistent asthma } \\
(\mathbf{n}=\mathbf{3 0 0})\end{array}$ & $\mathbf{t}$ & p value \\
\hline $\begin{array}{c}\text { Serum 25(OH)D } \\
\text { concentration }(\mathbf{n g} / \mathbf{m l})\end{array}$ & $26.49 \pm 5.92$ & $22.39 \pm 5.28$ & 4.229 & $<0.001$ \\
\hline
\end{tabular}




\section{DISCUSSION}

Asthma is a chronic inflammatory disorder of the airways that causes an increase in airways hyperresponsiveness, leading to recurrent episodes of wheezing, breathlessness, and coughing that are associated with variable airflow obstruction. ${ }^{6}$ However, it is well known that a positive atopic status, exposure and sensitization to environmental allergens, and/or familial history of allergic disease are significant risk factors associated with the development of asthma. 7,8 Many recent studies suggest that besides the already known risk factors, vitamin D deficiency is associated with and may even predispose one to the development of the allergy. ${ }^{9,10}$ So, These observations prompted us to conduct a cross-sectional study for seaching the relationship between vitamin $\mathrm{D}$ status and asthma in adult population.

It was found that asthmatic patients had significantly lower 25OHD levels than controls. Low levels of serum vitamin $\mathrm{D}$ is associated with impaired pulmonary function, increased incidence of inflammatory and infectious diseases. The exact mechanisms underlying these data appear to impact on the function of inflammatory and structural cells, including dendritic cells, lymphocytes, monocytes, and epithelial cells. ${ }^{11}$ Ginde, et al added that the association between serum Vitamin D level and upper respiratory infection was much stronger among individuals with asthma compared with those without asthma. ${ }^{12}$ This increased risk of respiratory infections may contribute to incident wheezing illness and cause asthma exacerbations. There may be a cause-and-effect relationship between vitamin $\mathrm{D}$ deficiency and the increased incidence of asthma

\section{REFERENCES}

1. Global Initiative for Asthma: GINA Report, Global Strategy for Asthma Management and Prevention - revised 2010. 2010. Available at: [www.ginasthma.org]

2. Camargo CA Jr,Rifas SL, Litonjua A et al. Maternal intake of vitamin $\mathrm{D}$ during pregnancy \& risk of recurrent wheeze in children at 3 y of age. Am J Clin Nutr 2007;85:788.

3. Bateman ED, Hurd SS, Barnes PJ, Bousquet J, Drazen JM, FitzGerald M, Gibson P, Ohta K, O'Byrene P, Pedersen SE, Pizzichini E, Sullivan SD, Wenzel SE, Zar HJ: Global strategy for asthma management and prevention: GINA executive summary. Eur Respir J 2008, 31:143-178. http://www.ncbi.nlm.nih.gov/pubmed/ 18166595.

4. Quanjer PH, Tammeling GJ, Cotes JE, et al. Lung volumes and forced ventilatory flows. Report of the Working Party Standardization of Lung Function Tests, European Community for Steel and Coal. Official Statement of the European Respiratory Society. Eur Respir J Suppl 1993;16:540.

5. Wagner D, Hanwell HEC, Vieth R . An evaluation of automated methods for measurement of serum 25hydroxyvitamin D. Clinical Biochemistry 2009;42:15491556.

6. Bateman ED, Hurd SS, Barnes PJ, Bousquet J, Drazen JM, FitzGerald M, et al. Global strategy for asthma management and prevention: GINA executive summary. Eur Respir J 2008;31:143-78. because vitamin $\mathrm{D}$ deficiency is associated with increased airway hyperresponsiveness, lower pulmonary functions, worse asthma control, and possibly steroid resistance. ${ }^{13}$ In addition lung epithelial cells express high baseline levels of $1 \alpha$-hydroxylase. This allows the conversion of inactive calcidiol to active calcitriol locally within the lung. Calcitriol has been shown to inhibit the synthesis and release of certain cytokines, such as platelet-derived growth factor, and matrix metalloproteinases, from bronchial smooth muscle cells, thereby leading to decreased lung inflammation and smooth muscle cell proliferation. More often a vitamin D insufficient diet was found significantly in the asthmatic group than in the healthy control group $(\mathrm{p}<0.001)$. The fear of allergic reaction against diet enriched with vitamin D might be reason in this area.

Another interesting finding in the study was that there was significant correlation between low 25 OHD level and the severity of asthma. These were in agreement with Brehm, et al who found that children with lower vitamin D levels were significantly more likely to have been hospitalized for asthma, tended to have airways with increased hyperreactivity and were likely to have used more inhaled corticosteroids, all signifying higher asthma severity. [14] Vitamin D deficiency increases the risk of severe asthma exacerbation and the need for emergency department evaluation or hospitalization.

\section{CONCLUSION}

The present study suggest that besides the already known risk factors, vitamin D deficiency is associated with and may even predispose one to the development of the allergic phenotype of bronchial asthma adults.

7. Stevens E, Cullinan P, Colvile R. Urban air pollution and children's asthma: what do parents and health professionals think? Pediatr Pulmonol 2004; 37:530-536.

8. Bener A, Ehlayel M, Sabbah A. The pattern and genetics of pediatric extrinsic asthma risk factors in polluted environment. Eur Ann Allergy Clin Immunol 2007; 39:58-63.

9. Ginde AA, Mansbach JM, Camargo CA Jr. Vitamin D, respiratory infections, and asthma. Curr Allergy Asthma Rep 2009; 9:81-87.

10. Chinellato I, Piazza M, Sandri M, Peroni D, Piacentini G, Boner AL Vitamin D serum levels and markers of asthma control in Italian children. J Pediatr 2011; 158:437-441.

11. Freishtat RJ, Iqbal SF, Pillai DK, Klein CJ, Ryan LM, Benton AS, et al.High prevalence of vitamin D deficiency among inner-city African American youth with asthma. J Pediatrics 2010; 156(6):948-52.

12. Ginde AA, Mansbach JM, Camargo CA Jr. Association between serum 25-hydroxyvitamin D level and upper respiratory tract infections in the Third National Health and Nutrition Examination Survey. Arch Intern Med 2009; 169(4):384-90.

13. Luong KV, Nguyen LT. The role of vitamin D in asthma. Annals of Allergy. Pulm Pharmacol Ther 2012; 25(2):137-43.

14. Brehm JM, Celedon JC, Soto-Quiros ME, Avila L, Hunninghake GM, Forno, et al. Serum vitamin D levels and markers of severity of childhood asthma in Costa Rica. Am J Respir Crit Care Med 2009;179(9): 765-71. 